\title{
Will Music Schools Embrace Multimedia Software?
}

\author{
Alec Johnson (University of Saint Thomas) \\ Jay Ebben (University of St. Thomas)
}

KEYWORDS: Entrepreneurship, Innovation, Angel Funding, Internet Business Models.

"If at first you don't succeed, try, try again. Then quit. There's no point in being a damn fool about it." - W.C. Fields

In the fall of 2010, Dejen Tesfiagiorgis sat in his tiny incubator office on the University of St. Thomas campus, contemplating the next move for his fledgling software start-up. For the past two years, he had been building a platform to streamline the process of receiving and evaluating applications to music schools and camps. Now, he was nearly out of cash as a result of spending $\$ 35,000$ with a software development firm that didn't deliver what they had promised. He had missed key deadlines with his first clients, and was finding it difficult to gain traction with new clients. With his ArtsApp business teetering on the brink of collapse, he needed to figure out how to keep moving forward.

\section{About ArtsApp}

ArtsApp provided audio and video file transferal service to music schools, summer camps and workshops, and additional creative arts organizations that require prescreened (auditioned) CD or DVD submissions. The service was peer-based, organizing media submissions from prospective students to adjudicating faculty. ArtsApp's service corresponded to the shift from hard copy music and video to digital, and was intended to address the time constraints faced by adjudicators, who needed to listen to up to 50 recordings in the span of two weeks. Rather than mailing hard-copy recordings to a central office, students would upload music and video to ArtsApp.com, where it would be organized and redistributed directly to faculty evaluators.

\section{Founding and Evolution}

Dejen arrived at The University of Saint Thomas in Minneapolis in 2004 to study music, specifically Jazz Saxophone and the Music Business program. The idea for ArtsApp officially hatched in 2006, Dejen's sophomore year at UST, driven by his personal

experience applying to music schools and music camps.

"There's a fine arts camp called Blue Lake and they require you to submit a CD to make sure you're a good performer. I filled out the application and then sent in my $C D$, and then I went to Facebook and shared, 'Okay, look what I just did.' I contacted my friends who were in music, and usually I'm up on the music scene. I started thinking back to when I was in high school and submitting my $C D$ for summer camps and intensives, and then also when I applied to New England Conservatory. I was applying to graduate schools for saxophone performance, submitting my $C D$ around, and then really seeing the lack of direct integration of schools with social networks, especially music schools. Some schools have a music fan page on Facebook, so they can do a lot of pushing of content, but they're not hearing a lot [because] it's not really a direct area for them to recruit and interact with students...To a 14-year-old, Facebook is something totally different than what it is to a 42-year-old arts administrator. So then the idea started brewing..."

In his junior year, Dejen declared Entrepreneurship as his major. He was feeling the tug to "do something in business," and continued to attend sessions with different student groups, including the Entrepreneurship Society and Practicing Entrepreneurs. He was also a dorm R.A., Vice President of the Band Club and member of Music Business Club, and volunteered regularly in middle school music programs.

In his final semester on campus, Dejen was voted the prestigious title of "Tommie of the Year" by classmates and faculty at the University of St. Thomas. It was also this semester that the idea for ArtsApp started to gain steam as he took his Entrepreneurship capstone course. He began the semester working with a partner to write a business plan around a music recording studio, but eventually decided to branch off on his own to research his own concept. 
"Some music schools were trying to recruit me, so I started asking them, 'How many CDs a year do you get? How do you communicate effectively with applicants? How are you using social networks to bridge that gap and maintain that interaction?' And they're saying, 'Those are good questions. We get 2,500 CDs a year or 1,200 for our summer programs.' I'm just making small talk, but still probing them for the answers to get an idea of market. And then I was hooked up with some really good administrators who I could just ask questions and just poke around through faculty here at St. Thomas. Really it started as research for a class project, but as I was getting more [excited about] it, I found I was spending my weekends and nights like this was [a real business]..."

\section{Changing Course}

Dejen decided he wanted to pursue this concept full time. However, his decision was not without risks, as he had applications under consideration with University of Indiana and New England Conservatory for graduate studies in music.

"When I decided to actually start the business and do this full time, it was... maybe around the end of February in 2008. I had an audition lined up at Indiana University, and that was the day I called them and I said, 'You know, I'm going to retract my application. I'm set on making this business, and l'm sure l'll be talking to you about it in about a year.' That's kind of the official date [l became an entrepreneur]..."

"I wanted to be a great player, but not necessarily world-known or internationally-known. And once I realized that, then it was easier for me to step away from practicing so much. Even recently l've said l've really got to get on these schools and devote literally like 6:00 a.m. to 7:00 p.m. making phone calls, because that's when people are open. That's when I can e-mail them and contact them. At night, I'm Skyping with my developers so we get that end going, and setting benchmarks and milestones. Just a way to constantly keep on top of the company, and that affects my ability and availability to perform and practice. But it's something that l've been okay to step away from because I'm just in another phase of my life that I can step away from it. I guess in high school I needed a thing. I wanted to be trained and well developed in something, so you don't get to college and then you're just a party boy ...you're someone who is passionate about something."

\section{The Pitch}

In order to help investors understand ArtsApp better, Dejen developed a day in the life scenario for a fictitious music school applicant, "Laura," applying at The Prestige Program as a specific example. Nearly all performing arts organizations in the target demographic used a similar process.

1. Laura is interested in studying violin at Prestige, so she fills out her general information and submits her application online. She has from October to April to apply for the program.

2. Laura then records herself performing her violin repertoire, and mails her $C D$ to the Admissions office at Prestige.

3. Once the Admissions office receives Laura's music, they archive her $C D$ with that of other violin applicants (Prestige receives roughly 3500 CD/DVD/VHS submissions every year for summer programs). Music can be held for up to six months, depending on when Laura applies and the application deadline.

4. Once the application deadline has closed, usually in late March or early April, the Admissions office mails CDs via postal mail or delivery service to the adjudicating faculty (usually college professors living across the country).

5. Faculty members listen to CDs (up to 50), select Laura as a student, inform the Admissions Office of their decision, and throw away the recorded $C D$. These adjudicators are given a one- to two-week period to make their decision.

6. The Admissions office informs Laura of her status.

\section{Saving Time and Freeing up Resources}

ArtsApp offered a faster process that would lower the cost of applicant management for the school. Admissions offices would no longer need to organize and archive the students' audition materials, or package and mail the CDs or other recordings to faculty members. This freed up their admissions office, and instructors could access the online media database $24 / 7$ through any web browser, or even download student recordings as a playlist to any media player. Students would upload media files to ArtsApp.com, specify their camp of choice, and ArtsApp would organize the music and distribute the digital media to the selected institutions. 
The largest and most competitive organizations receive the highest number of applicants, and require a greater responsibility from the office of admissions. These music organizations are quite competitive for entry and require applicants to audition either live or via recording for admittance. For instance, every summer Prestige received and archived 3,500 physical CDs and videotapes to supplement applications for their summer program, while Aspen Music Festival (Aspen, Colorado) received roughly $6,400 \mathrm{CD}$ s every year for its summer music festival. ${ }^{[1]}$

\section{In Dejen's words:}

"Each $C D$ is sent to admissions, then shipped to faculty, which becomes a significant cost to the admissions office. The convenience factor of storage and packaging to instructors is why my program will be used. ArtsApp frees up resources for admissions offices, and saves applicants' materials from being thrown away after use."

Every year, the Aspen Music Festival spent roughly $\$ 21,000$ to organize applicants' materials for their summer camp. Their staff included four paid staff and four volunteers, who worked for 40 hours a week for 16 weeks to manage the onslaught of applicant recordings. ArtsApp cut out steps 3 and 4 from above, and in doing so, Dejen believed a customer could cut one part-time employee for an immediate savings of $\$ 5,248$. In return, the school would pay ArtsApp a flat fee of up to $\$ 2,000$ a year.

\section{According to Dejen,}

"We're saving them the headache of file formats and physically managing these discs that are arriving. We also offer applicant support, but are moving away from this model and instead are building easier tools for a school to manipulate applications themselves, so our emails / calls directly from applicants and parents are kept to a minimum. From the applicant's perspective: The time they're saving by submitting online $+\sim \$ 5.00$ in shipping that they'd pay anyway."

\section{The Opportunity}

\section{Music and Performing Arts Education}

The music and performing arts education market (schools and universities) in the U.S. is approximately 800 institutions and 2.8 million applicants a year. In addition, hundreds of music and performing arts summer camps are targeted to grade school and high school students. Some of these camps, such as the Interlochen Summer Arts Camp in Michigan, accept as many as 2,500 students $^{[2]}$.

\section{Education Technology}

Education technology can be separated into four categories: 1) Content, 2) Instructional Support (such as testing and assessment), 3) Learning/Class Management, and 4) Special Categories (such as online courses). U.S. schools spent $\$ 7.4$ billion on education technology in the 2009 school year, an amount that was increasing by approximately $6 \%$ per year. The fastestgrowing segment was technology for online course delivery, while the largest segment was for

testing and assessment. Funding for education technology firms was increasing at a rate of approximately $30 \%$, with $\$ 385$ million in capital raised in $2009^{[3],[4]}$.

Some of the growth in education technology could be attributed to school policies, which were becoming more friendly to experimentation. In the early 2000 's, schools tended to purchase via request for proposals (RFP's), which was a lengthy and expensive process for ed-tech companies that could take up to two years. This was beginning to change, with a trend toward allowing companies to demo their technology in a live setting for 3-6 months to evaluate.

\section{University Spending}

In the wake of the recession, U.S. colleges and universities were experiencing significant pressure on budgets. For instance, the University of California system saw its budget cut by $27 \%$ between 2008 and $2012^{[5],}$ and state appropriations for the University of South Carolina system were cut by $47 \%$ between 2008 and $2010^{[6]}$. While budget cuts had begun to stabilize nationally by 2011 , education and related spending per student still decreased by approximately one percent from 2010 to $2011^{[7]}$.

\section{Trends in Digital Music Distribution}

Another important trend for ArtsApp was that of digital music distribution. The digital distribution model for music had been proven (for example, Apple's iTunes system sold over 5 million songs per day in $2006^{[8]}$ ) and was preferred by the age group of students who would be applying through the ArtsApp system. With the general shift away from hard copy CDs to digital 
distribution, experts were predicting that the next logical step for increasing efficiency was file sharing[9], because of the ease of developing web storage and digital archiving ${ }^{[10],[11]}$. Dejen was betting that this model could be easily applied to a focused customer base in an academic setting.

\section{Future Growth Opportunities}

Dejen saw several significant future opportunities for expansion in musical academia:

- Creating a user interface to be used as a general database service for University ensemble and student recordings

- Partnering with Blackboard Academic Suite to take advantage of their scalability and use in universities

- Partnering with educational music publishing companies such as Hal-Leonard, Increase Music, and others that send hard copy CDs as promotional material for selling print music

- Expanding into the market for musicians applying for federally funded music grants that require blind submissions for audio recordings

- Generating a unified application for all arts camps in the United States, providing letters of recommendation, general information, and music/video samples

\section{Competition}

ArtsApp had several competitors in digital media distribution. However, none of these targeted educational organizations, and were thus considered indirect competitors.

- Terrorbird Digital promoted Indie Rock and Alternative bands to college radio stations via broadband music downloads (zip files as mp3's). Terrorbird used virtual press kits instead of sending physical promos to radio stations.

- Sonic Bids provided online press kits for larger concert venues and rock festivals (such as South By Southwest) and specialized in Electronic Press Kits (EPKs) containing video, audio, tour dates and booking information for pop and indie music groups and promoters.

- Yousendit was a digital delivery company that allowed both commercial and individual customers to send, receive and track large files on-demand.
- Sendspace was another digital delivery service that provided up to $300 \mathrm{MB}$ of free internet transferal via email with no fees or membership requirements. This firm targeted large companies and corporations that shared large files.

- Virb was a website for high-quality audio files similar to MySpace, but with a higher quality of music. The website included detailed information on bands and their music, with available downloads.

Additionally, virtually all universities maintained their own information technologies and web development database with the potential for compatibility with their own music department's web storage needs. Finally, video-sharing services such as YouTube and Vimeo could potentially be used for submitting and sharing performance auditions.

\section{The Business Model}

The first iteration of the business model, as revealed in the business plan, focused on three revenue streams:

- The applicant would pay for bandwidth and storage space per file at a price of $\$ 11$.

- The institution would pay a membership fee for use of the server to hold and organize media This was a fixed membership cost of $\$ 500$ per organization, and a variable (tiered) cost per student uploading files to the program. The total cost would be roughly $\$ 4.00$ per student.

- The third revenue stream would be from an optional Google toolbar download, along with advertising from music camps, instrument manufacturers (such as Steinway pianos or Yamaha instruments), college music programs and other music related organizations.

Soon after launching, Dejen realized this was a more difficult sell than anticipated. First, the economy had slowed, hurting school enrollments. More importantly, Dejen was learning the buying behavior and cycle of schools, as well as their tolerance for technology risk.

"...it takes these schools more than I thought it would for them to sign up, or at least be interested, because they're getting swamped with vendors trying to sell them stuff constantly. I thought it was a big opportunity and I guess probably a little naive on saying we'll just put this up and then people will come to it. The thing is 
they get the value, but whether it's a timing or budget issue, they still move slow. Then the Director of Admissions has to consider their faculty, who are seasoned veterans of their instrument and probably not at all tech savvy."

Schools were slow to sign up and Dejen decided to go back to the drawing board. In the fall of 2010, he reached out to his entrepreneurship capstone professor, Alec Johnson. Dejen asked Professor Johnson to put together a group of entrepreneurs to whom Dejen could pitch his business and business model issue, trying to decide how much money to raise and how to move forward on sales. This group recommended that Dejen give the platform to schools for free for one year to reduce barriers to adoption, but to continue to charge students.

\section{Dejen recalled the rationale for this:}

"The schools don't know how it's going to interact with their current process, how the faculty are going to react to it. So just giving it away allows less uncertainty. We'd rather have you in for a year comfortable with the system, then it's $\$ 1,800$ we're going to get from you if you sign up for a membership. So just another way to ease that resistance from schools not wanting to sign up.

Conventionally if they say we don't have the budget this year, I'll say, 'This is going to save you $\$ 7,000$, and 100 man-hours of doing all this stuff,' and they'll say, 'We just don't have the budget...' Because they feel that I'm being pushy, when I'm just trying to be passionate about this. I want people to be using it and trying to break it, so it can be the best product possible. But some administrators saw it differently. 'It's not in our budget, so we're just not going to bother. Maybe contact us next spring or next year.' I couldn't wait 10 more months. We're going to have a whole new set of features and stuff up, and it's going to be even harder to explain what it is to you... And plus that's another year that I have to wait to get all this access to the students who are applying, access to the faculty who are at your school, and access to you as an institution."

\section{Software Development Process}

From launch in spring of 2008 to Fall of 2009, Dejen had invested $\$ 15,000$ of his own savings, most of that going to development of his platform. Because Dejen did not have a technology background, he hired X-Soft, a local web/software development firm, to build the platform. Dejen was trying to raise more money, but most investors wanted to see some level of proof of concept and initial sales before they would invest. In this process, Dejen learned from mentors that he needed a scope document, which was used by development firms to estimate the cost of development. The scope document and site map were intended to lay out every last function and feature of the site, as well as their relationship to each other. Dejen used the documents to interview several firms, finally settling on X-Soft.

Unfortunately, things didn't go as smooth as needed for an early stage company like ArtsApp:

"I guess my regret there is that they were willing to hold my hand, this company was willing to hold my hand, but the more hand-holding they do, the more expensive it is. So, if I had someone on my side, not contract labor but someone in software with whom I could partner going into it, they would have said, 'You have to spend two weeks, think about what every button on your site does. Make diagrams of what everything on the site does. Just really dig in..."'

"So, then once we had the scoping documents boarded out and lined up they said, 'Okay, it's going to cost about twice as much as what you have to build the system. And this is what it'll look like, and here's how it'll go.' And ideally the plan was we have a finished software product ready to show to schools on October 21 , and they'd have six weeks to play with it...At this point I could go back to investors who then would be willing to invest, so I could finish paying for the development work, my attorney, etc."

\section{The Setback}

Dejen completed a 40-page Scope Document from which X-Soft developed the platform, yet things just didn't progress as planned. During October 2009, Dejen began getting bad news from $\mathrm{X}$-Soft.

"Software is constant bug fixing and constant testing and redeployment and everything. So, okay, I can understand that, but are we still going to make our timeline? They said yes. And then it got closer and closer to the date, three weeks before their deadline, and they had showed me some basic things of what they had built. 'Okay, this is good. This is good progress. Are we still on track?' Yes, it's on track. So, two weeks later, it's one week before their deadline, 
and they showed me some more things, and they give me access to what they're working on. Okay, this looks good. And then literally a day before the deadline, it was a Friday, and I got an e-mail from the project manager that said, 'An emergency came up with another project, and we haven't been working on ArtsApp for the past two weeks. Sorry, we'll have it done mid-November.' The following Monday I had a meeting with the representative of a major, international music school, who was coming out to do some recruiting and happened to be in Minneapolis and said she'd meet with me. And so I wanted to show her a live system, not a PowerPoint of what we're working on. So that was huge, like a huge failure, because I had this milestone, this exact date benchmark."

Going forward, X-Soft missed a November deadline, then a December 2009 deadline. After some vetting of the process and the scoping document, Dejen was convinced that $X$-Soft had more than enough time and information to successfully complete the site, based on what had been negotiated. With just a basic, marginally functioning version of the site in hand, Dejen found himself in the awkward position of selling music schools, who could test with this incomplete platform and provide suggestions, but could not actually buy it.

However, this did allow him to argue to investors that he had proof of concept and market acceptance of the UVP, and through this was able to raise $\$ 35,000$ to hire a new development firm to essentially start over (see Appendix 1 for his Year 1 projected Income Statement and Balance Sheet). In starting over, Dejen applied previously learned lessons and recruited his good friends from high school, Terry Lundgren and Matt Krieger, a developer and database expert, to join the team and handle liaison responsibilities with the new firm. By July 2010, ArtsApp.com was back up, with a new design platform and their first client, The Juilliard School.

\section{Financing}

Dejen launched the business on personal savings along with money from family and friends, and began pitching for capital after hitting these milestones:

- Discussed the opportunity with several adjudicating faculty at summer music programs, and professional orchestras for use in their audition process

- Received support from Dr. Douglas Orzolok, former President President on the Board of the Minnesota Music Educators Association, and Jeffrey Kimpton, President of Interlochen Center for the Arts (hosts one of the largest high school arts summer programs in the US)

- Won First Place in The College of St. Catherine's 2008 Elevator Pitch Competition

- Designed the layout of a user interface for the website

- Began negotiations with software engineers to write the application

- Purchased a domain name, determined initial hosts for data storage

- Determined the most efficient methods for media transferal

He was finally able to close his first round of outside financing in late 2009 , which was $\$ 35,000$ structured as convertible, unsecured debentures with no interest payments the first year. The debentures would convert to $5 \%$ common stock (an implied valuation of $\$ 700,000)$. In 2010 , he raised a second round of $\$ 15,000$ in direct equity for $2.5 \%$ and converted the previous round at $2.5 \%$ (a provision in the previous agreement gave him the option of $2.5 \%$ or $5 \%$ under certain conditions). He also got his new development firm to defer $\$ 20,000$ of fees as debt to be paid off over a 12-month period.

\section{What Next?}

Despite raising additional capital in 2010 and deferring some of his development costs, Dejen found himself that fall with little cash in the bank. Even more concerning was the difficulties he was having with convincing new clients to give his platform a try. Coming out of his meeting with Professor Johnson and the group of entrepreneurs, giving his platform away made sense, but there were still a lot of questions with this strategy: How would schools respond? Would a free platform devalue his product? Would giving it free to new clients alienate his existing clients who had already paid? On top of this, Dejen had questions about the size of the market and the upside of his platform. With issues gaining traction in a niche market, how would he convince future investors to provide him with the cash he would need to continue to develop and grow?

Two years earlier, this had seemed like almost a slam dunk. Now, Dejen had more questions than answers. 


\section{Appendix 1 - Projected Year 1 Income Statement and Balance Sheet}

Projected Income Statement - Year 1

Month 1 Month 2 Month 3 Month 4 Month 5 Month 6 Month 7 Month 8 Month 9 Month 10 Month 11 Month 12 Tatal

Sales Revenue:

Audio from Applicant

Video from Applican

Membership Fees

Total Revenue

\begin{tabular}{ccccccccccccc}
891 & 4,455 & 3,713 & 3,564 & 5,049 & 5,495 & 5,940 & 594 & 149 & 149 & 149 & 149 & 30,294 \\
297 & 1,485 & 1,238 & 1,188 & 1,683 & 1,832 & 1,980 & 196 & 50 & 50 & 50 & 50 & 10,098 \\
420 & 2,101 & 1,751 & 1,680 & 2,381 & 2,591 & 2,801 & 280 & 70 & 70 & 70 & 70 & 14,284 \\
\hline 1,608 & 8,041 & 6,701 & 6,432 & 9,113 & 9,917 & 10,721 & 1,072 & 268 & 268 & 268 & 268 & 54,676
\end{tabular}

$\cos$

Gross Profit

\begin{tabular}{ccccccccccccc}
402 & 2,010 & 1,675 & 1,608 & 2,278 & 2,479 & 2,680 & 268 & 67 & 67 & 67 & 67 & 13,669 \\
\hline 1,206 & 6,030 & 5,025 & 4,824 & 6,835 & 7,438 & 8,041 & 804 & 201 & 201 & 201 & 201 & 41,007
\end{tabular}

Operating Expenses

Depreciation

EBIT

\begin{tabular}{|c|c|c|c|c|c|c|c|c|c|c|c|c|}
\hline 1,250 & 1,250 & 1,250 & 1.250 & 1,250 & 1.250 & 1.250 & 1,250 & 1,250 & 1,250 & 1,250 & 1,250 & 15,000 \\
\hline 206 & 206 & 206 & 205 & 206 & 206 & 206 & 206 & 206 & 206 & 206 & 206 & 2.475 \\
\hline-250 & 4,574 & 3,569 & 3,368 & 5,378 & 5,981 & 6.584 & -652 & $-1,255$ & $-1,255$ & $-1,255$ & $-1,255$ & 23,532 \\
\hline
\end{tabular}

Interest Expense

Income Taxes

Net Income

\begin{tabular}{ccccccccccccc}
460 & 440 & 440 & 440 & 460 & 440 & 440 & 440 & 440 & 440 & 440 & 440 & 5,280 \\
0 & 0 & 0 & 0 & 0 & 0 & 0 & 0 & 0 & 0 & 0 & 0 \\
\hline-690 & 4,134 & 3,129 & 2,928 & 4,938 & 5,541 & 6,144 & $-1,092$ & $-1,695$ & $-1,695$ & $-1,695$ & $-1,695$ & 18,252
\end{tabular}

Projected Balance Sheet - Year 1

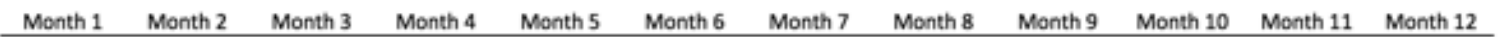

Assets

Cash

Inventory

Total Current Assets

Fixed Assets

Less: Acc. Depreciation

Net Fixed Assets

\begin{tabular}{cccccccccccc}
8,676 & 12,908 & 16,287 & 19,832 & 25,057 & 30,828 & 37,203 & 36,028 & 33,630 & 32,141 & 30,652 & 29,163 \\
113 & 563 & 469 & 450 & 638 & 694 & 750 & 75 & 19 & 19 & 19 & 19 \\
442 & 2,211 & 1,843 & 1,769 & 2,506 & 2,727 & 2,948 & 295 & 905 & 905 & 905 & 905 \\
\hline 9,231 & 15,682 & 18,598 & 22,051 & 28,201 & 34,250 & 40,902 & 36,398 & 34,553 & 33,064 & 31,575 & 30,086 \\
& & & & & & & & & & & \\
76,000 & 76,000 & 76,000 & 76,000 & 76,000 & 76,000 & 76,000 & 76,000 & 76,000 & 76,000 & 76,000 & 76,000 \\
203 & 405 & 608 & 810 & 1,013 & 1,216 & 1,418 & 1,621 & 1,824 & 2,026 & 2,229 & 2,431 \\
\hline 75,797 & 75,595 & 75,392 & 75,190 & 74,987 & 74,784 & 74,582 & 74,379 & 74,176 & 73,974 & 73,771 & 73,569 \\
85,028 & 91,277 & 93,990 & 97,241 & 103,188 & 109,034 & 115,484 & 110,777 & 108,729 & 107,038 & 105,346 & 103,655
\end{tabular}

Total Assets

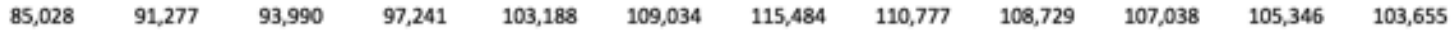

Liabilities

Accounts Payable

Accrued Expenses

Total Current Liabilities

\begin{tabular}{cccc}
402 & 2,513 & 2,094 \\
316 & 320 & 323 & 2,417 \\
\hline 718 & 2833 & 2417
\end{tabular}

Long-Term Debt

Equity

Paid-In Capital

Retained Earnings

Total Equity

$\begin{array}{llll}55,000 & 55,000 \quad 55,000 & 55,000 & 55,\end{array}$

Total Uiabilities and Equity

\begin{tabular}{|c|c|c|c|c|c|c|c|c|c|c|c|}
\hline 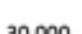 & 20000 & angm & 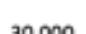 & 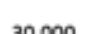 & 2000 & 3000 & $30 \mathrm{mo}$ & $20 \mathrm{mo}$ & 3000 & 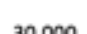 & $3 \mathrm{mo}$ \\
\hline 30,000 & 30,000 & $\begin{array}{l}30,000 \\
6573\end{array}$ & 30,000 & 30,000 & $\begin{array}{l}30,000 \\
0.980\end{array}$ & 30,000 & $\begin{array}{l}30,000 \\
25037\end{array}$ & $\begin{array}{l}30,000 \\
23,337\end{array}$ & 30,000 & $\begin{array}{l}30,000 \\
19047\end{array}$ & $\begin{array}{l}30,000 \\
18,55\end{array}$ \\
\hline $\begin{array}{c}-690 \\
9\end{array}$ & 3,444 & $\frac{6,573}{36573}$ & $\begin{array}{r}9,501 \\
39,501\end{array}$ & $\begin{array}{l}14,439 \\
\end{array}$ & $\begin{array}{r}19,980 \\
8980\end{array}$ & 26,124 & 25,032 & $\begin{array}{l}23,337 \\
53,337\end{array}$ & 21,642 & 19,947 & 18,252 \\
\hline
\end{tabular}

[1] Interview with Joan Gorden, Dean of Student Services, Aspen Music Festival and School, on 3.19.08

[2] camp.interlochen.org

[3] Chen, A. "The Ever-Growing Ed-Tech Market." The Atlantic. Nov. 6, 2015.

Copyright @ 2017 Alec Johnson, Jay Ebben, Published by Entrepreneur \& Innovation 
[4] Koba, M. "Education Tech Funding Soars, But is it Worth it in the Classroom?" Fortune. April 28, 2015.

[5] http://www.huffingtonpost.com/2013/10/19/university-of-california-budget_n_4103897.html

[6] https://www.sc.edu/budget_pdf/2011_budget_fact_sheet.pdf

[7] Trends in College Spending: 2003-2013. American Institutes for Research.

[8] “iTunes Store Sales Going Strong." Macworld, January 9, 2007.

[9] http://news.cnet.com/8301-17938_105-57321531-1/will-music-cds-be-dead-in-14-months/

[10] http://www.macobserver.com/tmo/article/music_cds_near_dead_ipods_fade/

[11] Daddy Kev, CEO Alpha Pup Digital, phone interview on, St. Paul, MN, March 2008.

Additional Search Terms: entrepreneurship courses, teaching ideas, teaching resources, classroom ideas, entrepreneurship classes, business schools, business school classes, entrepreneurship students, professors 